\title{
MENDUKUNG KEMUDAHAN BERUSAHA BAGI USAHA MIKRO, KECIL, DAN MENENGAH BERBADAN HUKUM DENGAN GAGASAN PENDIRIAN PERSEROAN TERBATAS OLEH PEMEGANG SAHAM TUNGGAL
}

\author{
(Supporting Ease Of Doing Business For Micro, Small, And Medium Enterprises In Legal Entity Form \\ Through Single Shareholder Idea In Limited Liability Company Establishment)
}

\author{
Fahrurozi \\ Direktorat Jenderal Administrasi Hukum Umum \\ Kementerian Hukum dan HAM RI \\ Jalan. H.R. Rasuna Said Kav X-6/8, Jakarta \\ Email: fahrurozi25@gmail.com
}

Naskah diterima: 18 Agustus 2018; revisi: 30 Oktober 2018; disetujui: 5 November 2018

\begin{abstract}
Abstrak
Kebijakan kemudahan berusaha yang diterapkan oleh Pemerintah diharapkan mampu mendorong Usaha Mikro, Kecil, dan Menengah (UMKM) untuk dapat meningkatkan perekonomian nasional. Meskipun UMKM memiliki kelebihan, UMKM juga memiliki beberapa kendala khususnya mengenai pembiayaan. Pembiayaan UMKM di Indonesia umumnya terkendala karena bentuk UMKM yang informal sulit untuk mendapatkan fasilitas bantuan atau pinjaman dana. Akibatnya, UMKM di Indonesia umumnya masih bermodalkan harta dan kekayaan pribadi pendirinya. Hal ini jelas mengganggu kelangsungan UMKM. Untuk mendapatkan fasilitas pembiayaan yang efektif, maka UMKM sudah waktunya berbentuk badan usaha formal dalam hal ini Perseoran Terbatas. Dengan metode yuridis normatif, tulisan ini akan berfokus pada pendekatan teoritis terhadap UMKM dan Perseroan Terbatas. Dari analisis kualitatif yang dilakukan, ditemukan fakta bahwa terdapat ketidakharmonisan antara Undang-undang Nomor 40 Tahun 2007 tentang Perseroan Terbatas dengan Undang-undang Nomor 20 Tahun 2008 tentang Usaha Mikro, Kecil, dan Menengah. Di mana ketentuan untuk mendirikan Perseroan Terbatas yang mensyaratkan didirikan minimum oleh 2 (dua) orang, dinilai tidak sejalan dengan konsep UMKM yang dapat didirikan dan dijalankan oleh 1 (satu) orang saja. Dari pemahaman di atas, tulisan ini menilai bahwa perlu adanya pembaruan hukum terkait hal tersebut.
\end{abstract}

Kata Kunci: kemudahan berusaha, perseroan terbatas, UMKM

\begin{abstract}
Ease of doing business policy is expected by the Government to improve national economics through Micro, Small and Medium Enterprise (UMKM). UMKM has its strength, but it also has constraints especially in financing issue. Financing UMKM through loan in Indonesia is generally difficult due to UMKM informality. Therefore, most UMKM in Indonesia are still funded privately. It is time for UMKM to be formally established, in this case is in Limited Liability Company (PT) form. With juridical normative method, this article will focus on theoretical approach regarding UMKM and PT. From qualitative analysis conducted, it is found that there is disharmony between Law Number 40 of 2007 on PT and Law Number 20 of 2008 on UMKM. It requires two persons to establish a PT, which against UMKM concept that can be established by just one person. This article assesses the urgency to reform the law regarding such issue.
\end{abstract}

Key Word: ease of doing business, limited liability company, UMKM 


\section{A. Pendahuluan}

Usaha Mikro, Kecil, dan Menengah (UMKM) kerap disebut sebagai salah satu penunjang perekonomian. UMKM identik dengan kelompok-kelompok pengusaha yang klasifikasi modal, aset, atau profitnya tergolong cukup rendah. Sehingga membutuhkan perlakuan tertentu agar usahanya dapat berjalan dengan baik. Indonesia melalui Undang-undang No. 20 Tahun 2008 tentang Usaha Mikro, Kecil, dan Menengah (UU UMKM), mendefinisikan UMKM melalui kategori independensi badan usaha, total kekayaan bersih dan hasil penjualan tahunan. ${ }^{1}$ Salah satu elemen penting dalam UU UMKM adalah "orang perorangan" dapat memulai UMKM.

Meskipun istilah UMKM muncul di Indonesia sejak disahkannya UU UMKM, praktek bisnis UMKM sudah dikenal sejak lama secara global. Dalam istilah Inggris, UMKM dalam dikenal dengan istilah "Small and Medium Enterprises" atau sering disingkat sebagai "SMEs". Esuh Ossai-Igwe Lucky mengatakan bahwa UMKM dapat ditentukan berdasarkan besarnya modal dan aset atau nilai profit yang dapat dihasilkan dari bisnis yang dijalankan. ${ }^{2}$ Selain itu, adapula pendapat yang mengklasifikasikan UMKM berdasarkan jumlah tenaga kerja yang dapat terserap. ${ }^{3}$ Pada pokoknya, Lucky menjelaskan bahwa definisi UMKM harus dilihat dari segi bisnis yang luas, tidak hanya terbatas pada ukuran besarnya perusahaan atau seberapa banyak tenaga kerja yang dapat terserap. Sebagai contoh, bisa saja suatu perusahaan hanya terdiri dari 1 (satu) orang pekerja yang merangkap pendiri perusahaan namun memiliki aset yang besar sehingga tidak dapat dikategorikan sebagai UMKM.

UMKM dianggap sebagai elemen penting dalam perekonomian internasional. Uni Eropa mengklaim bahwa UMKM merepresentasikan 99\% bisnis di Uni Eropa. ${ }^{4}$ Dalam 5 (lima) tahun terakhir, UMKM telah menciptakan $85 \%$ lapangan kerja dan menyerap 2/3 (dua per tiga) ketenagakerjaan sektor privat. ${ }^{5}$

Angka ini menunjukkan signifikansi UMKM dalam menunjang perekonomian Uni Eropa sebagai suatu entitas negara-negara yang perekonomiannya dapat dikatakan paling baik di dunia. Secara khusus World Bank mengamini pentingnya UMKM khususnya bagi negara-

Kategorisasi ini terdapat dalam Pasal 1 UU UMKM:

1. Usaha Mikro adalah usaha produktif milik orang perorangan dan/atau badan usaha perorangan yang memenuhi kriteria Usaha Mikro sebagaimana diatur dalam Undang-Undang ini.

2. Usaha Kecil adalah usaha ekonomi produktif yang berdiri sendiri, yang dilakukan oleh orang perorangan atau badan usaha yang bukan merupakan anak perusahaan atau bukan cabang perusahaan yang dimiliki, dikuasai, atau menjadi bagian baik langsung maupun tidak langsung dari Usaha Menengah atau Usaha Besar yang memenuhi kriteria Usaha Kecil sebagaimana dimaksud dalam Undang-Undang ini.

3. Usaha Menengah adalah usaha ekonomi produktif yang berdiri sendiri, yang dilakukan oleh orang perorangan atau badan usaha yang bukan merupakan anak perusahaan atau cabang perusahaan yang dimiliki, dikuasai, atau menjadi bagian baik langsung maupun tidak langsung dengan Usaha Kecil atau Usaha Besar dengan jumlah kekayaan bersih atau hasil penjualan tahunan sebagaimana diatur dalam Undang-Undang ini.

2 Esuh Ossai-Igwe Lucky, "Is Small and Medium (SMEs) an Enterpreneurship?" Human Resource Management Academic Research http://www.hrmars.com/admin/pics/545.pdf Society (diakses pada 12 September 2018). Ibid.

4 Growth: Internal Market, Industry, Entrepreneurship and SMEs, "Entrepreneurship and Small and mediumsized enterprises", European Union https://ec.europa.eu/growth/smes_en (diakses pada 12 September 2018).

5 Ibid. 
negara berkembang. ${ }^{6}$ UMKM formal yang terdaftar secara resmi berkontribusi hingga $45 \%$ dari total penyerapan tenaga kerja dan 33\% dari Produk Domestik Bruto (PDB) di negara berkembang. ${ }^{7}$ Angka tersebut belum mengakomodir UMKM informal yang tidak terdaftar secara resmi misalnya seperti pedagang kaki lima yang belum terdata. Berdasarkan estimasi World Bank, 600 juta pekerjaan akan dibutuhkan dalam 15 tahun kedepan untuk menyerap tenaga kerja di Asia dan Afrika. ${ }^{8}$

Secara global, UMKM dan wirausaha memiliki keterkaitan yang erat. Organization for Economic Co-operation and Development (OECD) mengklasifikasikan UMKM dan wirausaha sebagai suatu kesatuan dan memiliki tujuan yang sama, yaitu mendukung pertumbuhan ekonomi, penciptaan lapangan kerja, dan berperan penting dalam kohesi dan integrasi sosial. ${ }^{9}$ Sedangkan Uni Eropa menambahkan bahwa UMKM merupakan salah satu metode yang dapat mendorong wirausaha karena UMKM memiliki akses-akses dan kemudahan lainnya dibandingkan pola wirausaha lama. ${ }^{10}$ Dengan demikian, sebagai salah satu negara berkembang di wilayah Asia,
Pemerintah Indonesia perlu terus menopang keterselenggaraan UMKM.

Dalam beberapa dekade terakhir di Indonesia, UMKM semakin mendapat perhatian masyarakat yang ingin melakukan usaha namun memiliki keterbatasan sumber daya khususnya finansial. UMKM merupakan bagian penting dunia usaha yang mempunyai kedudukan, potensi, peranan yang strategis dalam mewujudkan struktur perekonomian nasional yang makin seimbang berdasarkan demokrasi ekonomi. ${ }^{11}$ Seiring perkembangan ekonomi, peran UMKM dalam perekonomian domestik semakin meningkat khususnya paska krisis nasional tahun $1997 .{ }^{12}$ Saat ini, UMKM memiliki peran strategis dalam struktur perekonomian Indonesia, dimana sekitar 99,9\% unit bisnis di Indonesia merupakan UMKM. ${ }^{13}$

Pada masa krisis moneter 1998, UMKM menunjukkan kemampuannya dalam menghadapi krisis, sedangkan usaha besar banyak yang terpuruk karena banyak bergantung pada pinjaman luarnegeri. ${ }^{14}$ Kemampuan UMKM sebagaimana dimaksud adalah kemampuan dalam mengalirkan dana (cash flow) dari dan ke masyarakat sehingga kegiatan perekonomian

6 The World Bank, "Small And Medium Enterprises (Smes) Finance: Improving SMEs' access to finance and finding innovative solutions to unlock sources of capital." https://www.worldbank.org/en/topic/smefinance (diakses pada 13 September 2018).

Ibid.

$8 \quad$ Ibid.

9 OECD, "OECD Studies on SMEs and Entrepreneurship", OECD iLibrary, https://www.oecd-ilibrary.org/industryand-services/sme-and-entrepreneurship-policy-in-israel-2016_9789264262324-en.

10 Growth: Internal Market, Industry, Entrepreneurship and SMEs, "Promoting entrepreneurship" European Union, https://ec.europa.eu/growth/smes/promoting-entrepreneurship_en (diakses pada 12 September 2018).

11 Bank Indonesia, "Kajian Inkubator Bisnis dalam rangka Pengembangan UMKM" , Kajian dan Publikasi Sektor Riil Bank Indonesia, http://www.bi.go.id/id/umkm/penelitian/nasional/kajian/Pages/riil6.aspx. (diakses pada 11 September 2018).

12 Ibid.

13 Ade Irawan Taufik, "Evaluasi Regulasi Dalam Menciptakan Kemudahan Berusaha Bagi UMKM", Jurnal Rechtsvinding, Volume 6 Nomor 3 (2017), https://rechtsvinding.bphn.go.id/jurnal/680030JURNAL\%20 VOLUME\%206\%20NO\%203_rev\%202.pdf (diakses pada 16 September 2018).

14 Bank Indonesia, "Kajian Inkubator Bisnis dalam rangka Pengembangan UMKM, Op.Cit. 
nasional khususnya untuk pemenuhan pangan tetap dapat dipenuhi. Selain daripada itu, keseriusan Pemerintah Indonesia mendukung UMKM dapat dilihat dalam usaha Pemerintah menembus peringkat 40 (empat puluh) besar program Ease of Doing Business (EoDB). EoDB merupakan survei yang diselenggarakan oleh World Bank, dimana EoDB terdiri atas 10 (sepuluh) indikator untuk meningkatkan iklim berbisnis di 189 negara di dunia. ${ }^{15}$ Kesepuluh indikator tersebut adalah: aspek memulai usaha, pengurusan izin konstruksi, akses mendapatkan listrik, pendaftaran properti, mendapatkan kredit, perlindungan terhadap pemegang saham minoritas, pembayaran pajak, perdagangan lintas perbatasan, penegakan kontrak, dan penyelesaian kepailitan. Pada tahun 2018, Indonesia menduduki peringkat 72 setelah sebelumnya menduduki peringkat 91 pada tahun 2017. Pada tahun 2016, Indonesia menduduki peringkat 109 setelah sebelumnya pada tahun 2015, Indonesia berada pada peringkat $120 .{ }^{16}$

World Bank juga menyebut bahwa apabila kesepuluh indikator tersebut mendapatkan penilaianyang baikdarihasilsurveikepada pelaku usaha sebagai responden, maka hal ini tidak hanya berdampak positif bagi UMKM saja, tetapi dunia bisnis Indonesia secara keseluruhan. ${ }^{17}$ Namun demikian, Komite Pemantauan Pelaksanaan Otonomi Daerah (KPPOD) dalam penelitiannya menyampaikan bahwa dari instrumen studi dan indikator EoDB, kemudahan berusaha yang diadvokasi jelas menyasar kepada bisnis skala UMKM. ${ }^{18}$ Menariknya, EoDB hanya memberikan penilaiannya terhadap bentuk usaha PT (Standardized Company). ${ }^{19}$ Artinya secara tidak langsung, kebijakan EoDB yang bermanfaat untuk UMKM di Indonesia, hanya akan mendapat pengakuan positif dari World Bank apabila UMKM tersebut berbentuk PT. Padahal, dalam Undang-undang No. 40 Tahun 2007 Tentang Perseroan Terbatas (UUPT) mensyaratkan bahwa PT harus didirikan minimum 2 (dua) orang. Hal ini tentu kontras dengan semangat UMKM di Indonesia sendiri yang mendorong orang-perorangan untuk melakukan bisnis UMKM. Berdasarkan uraian singkat di atas, tulisan ini bertujuan untuk membahas mengenai pentingnya sistem hukum Indonesia mengkomodir gagasan PT agar dapat didirikan oleh 1 (satu) orang, demi mendukung bisnis UMKM dalam rangka meningkatkan peringkat Indonesia dalam survei EoDB.

\section{B. Metode Penelitian}

Metode yang digunakan dalam penelitian ini adalah yuridis normatif. Metode yuridis normatif merupakan metode yang menekankan penggunaan data sekunder. ${ }^{20}$ Adapun metode pengumpulan data sekunder yang digunakan pada penelitian ini adalah metode penelitian

15 The World Bank, "About Doing Business", http://www.doingbusiness.org/content/dam/doingBusiness/media/ Annual-Reports/English/DB18-Chapters/DB18-About-Doing-Business.pdf (diakses pada 13 September 2018).

16 The World Bank Group, "Doing Business 2018: Reforming Business to Create Jobs", The World Bank Group Flagship Report, http://www.doingbusiness.org/content/dam/doingBusiness/country/i/indonesia/IDN.pdf (diakses pada 14 September 2018).

17 Ibid.

18 Ibid.

19 Ibid.

20 Sri Mamudji, Et. Al., Metode Penelitian dan Penulisah Hukum, (Jakarta: Badan Penerbit Fakultas Hukum Universitas Indonesia, 2005), hlm. 6. 
kepustakaan. Metode penelitian kepustakaan ini penekanannya pada analsis data sekunder yang bersumber dari peraturan perundangundangan, buku-buku, dokumen resmi, publikasi dan hasil penelitian. ${ }^{21}$ Peraturan perundanganundangan yang dimaksud meliputi peraturan dalam bidang hukum perdata khususnya terkait organisasi perusahaan. Sedangkan untuk bukubuku, jurnal atau hasil penelitian yang digunakan berfokus pada tulisan mengenai kemudahan berusahan dan prinsip-prinsip UMKM.

Adapun metode analisis data yang digunakan dalam penelitian ini adalah metode analisis kualitatif. Analisis kualitatif maksudnya adalah suatu metode penelitian yang menghasilkan bentuk penelitian deskriptif analitis. ${ }^{22}$ Dimana hasil penelitian dinyatakan secara lisan atau tertulis. ${ }^{23}$ Penelitian ini juga tidak dilakukan dengan tahap pengukuran berupa statistik dan sebagainya.

\section{Pembahasan}

1. Ciri dan Karakteristik Usaha Mikro, Kecil, dan Menengah

\section{a. Prinsip dasar Usaha Mikro, Kecil, dan Menengah}

Untuk melihat mengapa UMKM menjadi perhatian Pemerinah, kita perlu melihat secara mendalam apa itu UMKM dan mengapa UMKM tidak dapat disamakan dengan bisnis biasa. Sebagai jenis usaha yang mempunyai karakteristik khusus, maka perlu dilihat prinsipprinsip dasar UMKM dan apa tujuan yang ingin dicapai. Secara garis besar di Indonesia, prinsip tersebut dapat dilihat dalam asas-asas UMKM yang dapat ditemukan dalam Pasal 2 UU UMKM yaitu asas: ${ }^{24}$

1) kekeluargaan;

2) demokrasi ekonomi;

Zainuddin Ali, Metode Penelitian Hukum, (Jakarta: Sinar Grafika,2010), hlm. 107.

Sri Mamudji, Op Cit., hlm. 67.

Ibid.

24 Dalam penjelasan Pasal 2 UU UMKM dijabarkan mengenai pengertian asas-asas tersebut sebagai berikut:

- Yang dimaksud dengan "asas kekeluargaan" adalah asas yang melandasi upaya pemberdayaan Usaha Mikro, Kecil, dan Menengah sebagai bagian dari perekonomian nasional yang diselenggarakan berdasar atas demokrasi ekonomi dengan prinsip kebersamaan, efisiensi berkeadilan, berkelanjutan, berwawasan lingkungan, kemandirian, keseimbangan kemajuan, dan kesatuan ekonomi nasional untuk kesejahteraan seluruh rakyat Indonesia.

- Yang dimaksud dengan "asas demokrasi ekonomi" adalah pemberdayaan Usaha Mikro, Kecil, dan Menengah diselenggarakan sebagai kesatuan dari pembangunan perekonomian nasional untuk mewujudkan kemakmuran rakyat.

- Yang dimaksud dengan "asas kebersamaan" adalah asas yang mendorong peran seluruh Usaha Mikro, Kecil, dan Menengah dan Dunia Usaha secara bersama-sama dalam kegiatannya untuk mewujudkan kesejahteraan rakyat.

- Yang dimaksud dengan "asas efisiensi berkeadilan" adalah asas yang mendasari pelaksanaan pemberdayaan Usaha Mikro, Kecil, dan Menengah dengan mengedepankan efisiensi berkeadilan dalam usaha untuk mewujudkan iklim usaha yang adil, kondusif, dan berdaya saing.

- Yang dimaksud dengan "asas berkelanjutan" adalah asas yang secara terencana mengupayakan berjalannya proses pembangungan melalui pemberdayaan Usaha Mikro, Kecil, dan Menengah yang dilakukan secara berkesinambungan sehingga terbentuk perekonomian yang tangguh dan mandiri.

- Yang dimaksud dengan "asas berwawasan lingkungan" adalah asas pemberdayaan Usaha Mikro, Kecil, dan Menengah yang dilakukan dengan tetap memperhatikan dan mengutamakan perlindungan dan pemeliharaan lingkungan hidup.

- Yang dimaksud dengan "asas kemandirian" adalah asas pemberdayaan Usaha Mikro, Kecil, dan Menengah yang dilakukan dengan tetap menjaga dan mengedepankan potensi, kemampuan, dan kemandirian Usaha Mikro, Kecil, dan Menengah. 

3) kebersamaan;
4) efisiensi berkeadilan;
5) berkelanjutan;
6) berwawasan lingkungan;
7) kemandirian;
8) keseimbangan kemajuan; dan
9) kesatuan ekonomi nasional.

Adapun tujuan daripada UMKM di Indonesia adalah menumbuhkan dan mengembangkan usaha dalam rangka membangun perekonomian nasional berdasarkan demokrasi ekonomi yang berkeadilan. ${ }^{25}$ Sebagai pembanding, Uni Eropa (UE) memiliki The Small Business Act (SBA) yang merupakan peraturan yang mengatur mengenai UMKM bagi negara anggota Uni Eropa. UMKM di Uni Eropa memiliki asas-asas yang sifatnya jauh lebih sederhana dibandingkan dengan asas-asas dalam UU UMKM yaitu: ${ }^{26}$

1) Promoting entrepreneurship (mendorong wirausaha). Mengingat laju pertumbuhan penduduk yang pesat serta angka migrasi yang tinggi, maka Uni Eropa berupaya mendorong sumber daya manusia yang ada untuk melakukan wirausaha. Dengan semakin banyaknya sumber daya manusia yang memilih untuk berwirausaha, maka akan muncul lapangan kerja baru yang secara otomatis mampu menyerap angka pengangguran;

2) Less regulatory burden (mengurangi peraturan yang menghambat). SBA diterbitkan oleh Uni Eropa tidak lain dimaksudkan agar seluruh negara di Eropa juga memberikan kemudahan untuk mendukung UMKM. Salah satu cara yang dikampanyekan adalah mengurangi peraturan yang menghambat aktivitas UMKM baik itu terkait pendirian maupun dalam hal melaksanakan usahanya. Hal ini juga dikenal dengan istilah deregulasi;

3) Access to finance (akses untuk pendanaan). Salah satu kendala UMKM adalah kemudahan dalam mendapatkan pendanaan, baik itu di awal pendirian maupun dalam melaksanakan usahanya. Terutama bagi UMKM yang merupakan perusahaan perorangan atau badan usaha informal lainnya. Hal ini dikarenakan perusahaan pembiayaan dan perbankan merasa ragu dengan kemampuan UMKM dalam membayarkan utangnya. Selain itu, minimnya aset baik harta bergerak/ tidak bergerak membuat sulit bagi UMKM menjaminkan hartanya. Maka dari itu, SBA juga mengharapkan agar negara-negara anggota EU dan pelaku usaha pembiayaan lebih memberikan kemudahan bagi UMKM untuk mendapatkan pendanaan.

4) Access to markets and internationalisation (akses menuju pasar dan internasionalisasi). Dengan keterbatasan biaya produksi, tentu saja untuk melakukan pemasaran UMKM akan mengalami kesulitan. Maka dari itu, Uni Eropa juga berupaya agar UMKM mampu menemukan target pasar sehingga

- Yang dimaksud dengan "asas keseimbangan kemajuan" adalah asas pemberdayaan Usaha Mikro, Kecil, dan Menengah yang berupaya menjaga keseimbangan kemajuan ekonomi wilayah dalam kesatuan ekonomi nasional.

- Yang dimaksud dengan "asas kesatuan ekonomi nasional" adalah asas pemberdayaan Usaha Mikro, Kecil, dan Menengah yang merupakan bagian dari pembangunan kesatuan ekonomi nasional.

25 Ibid., Pasal 3.

26 European Union, "Think Small First" - A "Small Business Act", European", EUR-Lex, http://eur-lex.europa.eu/ legal-content/EN/TXT/?uri=CELEX:52008DC0394 (diakses pada 14 September 2018). 
bisnisnya sampai kepada konsumen. Selain itu, meskipun di satu sisi mereka mengakui bahwa UMKM masih mengalami kendala dalam pendanaan, Uni Eropa juga tetap memiliki visi agar UMKM mampu beroperasi secara global. Uni Eropa mendorong bagi para negara untuk terus memberikan kemudahan agar UMKM di Uni Eropa mampu menghasilkan produk bertaraf internasional, yang selanjutnya diharapkan mampu menjadi perusahaan besar dengan skala internasional pula. Hal ini tidak ditemukan dalam UU UMKM.

Selain daripada asas, SBA juga juga memiliki tujuan spesifik dalam penyelenggaraan UMKM di Uni Eropa. Tujuannya adalah meningkatkan pendekatan kewirausahaan di Eropa, mensimplifikasi peraturan dan kebijakan untuk UMKM, serta menghilangkan hambatan yang ada untuk pengembangan bisnis UMKM. ${ }^{27}$

Di sisi lain, World Bank secara prinsip hanya menargetkan agar UMKM mampu menyerap tenaga kerja khususnya bagi negara-negara berkembang. ${ }^{28}$ Meskipun terkesan sederhana, upaya World Bank dalam mewujudkan UMKM yang mampu menyerap tenaga kerja dilakukan melalui berbagai macam kebijakan khususnya terkait dengan pendanaan. ${ }^{29}$ Salah satu upaya dalam mewujudkan UMKM yang mampu menyerap tenaga kerja dengan maksimal adalah indikator usaha dalam EoDB. Instrumen dalam 10 (sepuluh) indikator EoDB dirancang agar mendukung kemudahan bagi UMKM dalam melaksanakan usahanya.

\section{b. Kriteria Usaha Mikro, Kecil, dan Menengah}

Pada pendahuluan telah dijelaskan sebelumnya bahwa kriteria UMKM di Indonesia berdasarkan pada kekayaan bersih dan hasil penjualan tahunan. Maka dari itu, dalam bagian ini akan dijelaskan lebih mendalam mengenai klasifikasi kekayaan bersih bagi jenis UMKM. Mengenai Usaha Mikro, dalam istilah asing UMKM (SMEs) tidak terdapat adanya kata "micro" karena singkatan tersebut hanya terdiri dari small (Usaha Kecil) dan medium (Usaha Menengah). Akan tetapi dalam implementasinya, jenis Usaha Mikro banyak yang digolongkan sebagai bagian dari Usaha Kecil. Sebagai pembanding, di Amerika Serikat Usaha Mikro digolongkan sebagai bagian dari terkecil dari UMKM dengan melihat jumlah pekerja yang dipekerjakan. ${ }^{30}$ Biro Sensus Amerika Serikat mengkategorikan Usaha Mikro sebagai: SOHO (Small Office - Home Office), non-employer business (maksudnya tidak ada pemberi kerja/atasan), dan non-employee business (maksudnya bisnis yang tidak memiliki pekerja termasuk bisnis yang kurang dari 5 (lima) pegawai). ${ }^{31}$

Adapun di Indonesia, kriteria Usaha Mikro adalah memiliki kekayaan bersih paling banyak Rp 50.000.000,00 (lima puluh juta rupiah) tidak termasuk tanah dan bangunan tempat usaha, atau memiliki hasil penjualan tahunan

\footnotetext{
European Union, "Think Small First" - A "Small Business Act", European", Op.Cit.

28 World Bank, "Small And Medium Enterprises (Smes) Finance: Improving SMEs' access to finance and finding innovative solutions to unlock sources of capital.", Op.Cit.

29 Ibid.

30 Esuh Ossai-Igwe Lucky, "Is Small and Medium (SMEs) an Enterpreneurship?", Op.Cit.

31 Ibid.
} 
paling banyak Rp300.000.000,00 (tiga ratus juta rupiah). ${ }^{32}$ Kriteria Usaha Kecil adalah memiliki kekayaan bersih lebih dari Rp 50.000.000,00 (lima puluh juta rupiah) sampai dengan paling banyak Rp 500.000.000,00 (lima ratus juta rupiah) tidak termasuk tanah dan bangunan tempat usaha, atau memiliki hasil penjualan tahunan lebih dari Rp300.000.000,00 (tiga ratus juta rupiah) sampai dengan paling banyak Rp2.500.000.000,00 (dua milyar lima ratus juta rupiah). ${ }^{33}$

Secara garis besar, kriteria Usaha Kecil dalam UU UMKM memiliki kemiripan dengan definisi Usaha Kecil menurut Lucky, yaitu usaha yang yang lebih besar dari Usaha Mikro dari segi ukuran, jumlah pekerja, struktur, modal, dan kontribusi ekonomi. ${ }^{34}$ Sedangkan Usaha Menengah tentu saja lebih besar daripada kedua jenis usaha tersebut. Terkait Usaha Mikro dan Kecil, di beberapa Negara terdapat perbedaan kriteria jumlah pekerja dengan penekanan bahwa maksimum mempekerjakan 249 pekerja di Inggris, 250 di Uni Eropa, 200 di Australia dan 500 di Amerika Serikat. ${ }^{35}$ Artinya, tiap negara bisa memiliki kriteria UMKM yang berbedabeda namun parameternya memiliki pola yang sama (jumlah pekerja, aset, dan lainnya).

Dalam UU UMKM, kriteria Usaha Menengah adalah memiliki kekayaan bersih lebih dari Rp500.000.000,00 (lima ratus juta rupiah) sampai dengan paling banyak Rp10.000.000.000,00 (sepuluh milyar rupiah) tidak termasuk tanah dan bangunan tempat usaha, atau memiliki hasil penjualan tahunan lebih dari Rp 2.500.000.000,00 (dua milyar lima ratus juta rupiah) sampai dengan paling banyak Rp 50.000.000.000,00 (lima puluh milyar rupiah). ${ }^{36}$ Diatas nominal tersebut, maka usaha tersebut dapat digolongkan sebagai usaha besar. Akan tetapi, nilai nominal bagi UMKM tersebut dapat diubah sewaktu-waktu sesuai dengan perkembangan perekonomian yang nantinya diatur secara khusus dengan Peraturan Presiden. ${ }^{37}$

\section{c. Kendala Usaha Mikro, Kecil, dan Menengah}

PentinguntukdiingatbahwasekalipunUMKM memiliki peran yang kuat dalam perekonomian global, UMKM memiliki beberapa kendala dalam pengimplementasiannya khususnya di Indonesia. Badan Perencanaan Pembangunan Nasional (Bappenas) merangkum hal-hal yang menjadi kendala bagi UMKM untuk dapat berkembang di Indonesia: ${ }^{38}$

1) Tingkat produktivitas rendah. Meskipun secara kuantitas, jumlah UMKM meningkat, namun hal ini tidak berbanding lurus dengan

32 Dalam penjelasan Pasal 6 ayat (1) UU UMKM disebutkan bahwa yang dimaksud dengan "kekayaan bersih" adalah hasil pengurangan total nilai kekayaan usaha (aset) dengan total nilai kewajiban, tidak termasuk tanah dan bangunan tempat usaha. Sedangkan yang dimaksud dengan "hasil penjualan tahunan" adalah hasil penjualan bersih (netto) yang berasal dari penjualan barang dan jasa usahanya dalam satu tahun buku.

33 Pasal 6 ayat (2) UU UMKM.

34 Esuh Ossai-Igwe Lucky, "Is Small and Medium (SMEs) an Enterpreneurship?", Op.Cit.

Ibid.

Pasal 6 Ayat (3) UU UMKM.

Pasal 6 Ayat (4) UU UMKM.

38 Kantor Menteri Negara Perencanaan Pembangunan Nasional (BAPPENAS), "Empowerment of Cooperatives and Micro, Small, and Medium Enterprise", https://www.bappenas.go.id/files/8913/4986/4554/chapter20-empowerment-of-cooperatives-and-micro-small-and-medium-enterprise.pdf (Diakses pada 23 September 2018). 
produktivitas dan kualitas. Terutama untuk usaha jenis mikro. Hal ini menjadikan UMKM harus meningkatkan produktivitasnya guna mampu bersaing dengan jenis usaha besar. Menurut Bappenas, hal ini disebabkan oleh beberapa faktor. Faktor tersebut adalah rendahnya kualitas sumber daya manusia, keterbatasan dalam manajemen, keorganisasian, penguasaan teknologi, dan pemasaran UMKM, serta rendahnya kompetensi kewirausahaan dalam UMKM. ${ }^{39}$

2) Terbatasnya akses untuk mendapatkan sumber daya, khususnya permodalan, teknologi, informasi dan pemasaran. Meskipun UMKM memiliki beberapa keunggulan sebagaimana telah dijelaskan sebelumnya, UMKM memiliki permasalahan khusus terkait pendanaan. World Bank menilai bahwa UMKM dianggap lebih sulit untuk mendapatkan pinjaman bank dibanding perusahaan besar. ${ }^{40}$ UMKM kerap bergantung pada modal dan harta pribadi untuk menjalankan usahanya. Dimana apabila UMKM mengalami utang atas harta pribadi, maka bukan hanya bisnisnya saja yang bankrut, tetapi harta pribadinya pun dapat terkena imbasnya.

Secara yuridis, kekhawatiran pendanaan tersebut sudah diakomodir dalam Pasal 21 UU UMKM. Dimana Pemerintah Pusat dan Pemerintah Daerah menyediakan pembiayaan bagi Usaha Mikro dan Usaha Kecil. ${ }^{41}$ Akan tetapi, tidak dijelaskan secara pasti mengenai frase "menyediakan pembiayaan" tersebut dan mekanismenya. Secara analogi, ketentuan tersebut memungkinkan adanya pembiayaan yang bersumber dari Anggaran Pendapatan dan Belanja Negara (APBN) atau Anggaran Pendapatan dan Belanja Daerah (APBD). Ketentuan tersebut juga memungkinkan adanya pembiayaan melalui PNBP atau diberikan oleh badan usaha swasta (berupa hibah) yang Pemerintah Pusat maupun Pemerintah Daerah bertindak sebagai fasilitator saja. Perlu diingat dalam hal ini, fasilitas tersebut hanya untuk jenis Usaha Mikro dan Usaha Kecil saja. Tidak diberikan pada Usaha Menengah.

Selain daripada Pemerintah, Badan Usaha Milik Negara (BUMN) juga dapat menyediakan pembiayaan dari penyisihan bagian laba tahunan yang dialokasikan kepada Usaha Mikro dan Kecil dalam bentuk pemberian pinjaman, penjaminan, hibah, dan pembiayaan lainnya. ${ }^{42}$ Usaha Besar nasional dan asing juga dapat menyediakan pembiayaan yang dialokasikan kepada Usaha Mikro dan Kecil dalam bentuk pemberian pinjaman, penjaminan, hibah, dan pembiayaan lainnya. ${ }^{43}$ Adapun Pemerintah, Pemerintah Daerah, dan dunia usaha dapat memberikan hibah, mengusahakan bantuan luar negeri, dan mengusahakan sumber pembiayaan lain yang sah serta tidak mengikat untuk Usaha Mikro dan Kecil. ${ }^{44}$ Pemerintah dan Pemerintah Daerah juga dapat memberikan insentif dalam

\footnotetext{
Ibid.

40 The World Bank, "Small And Medium Enterprises (Smes) Finance: Improving SMEs' access to finance and finding innovative solutions to unlock sources of capital.", Op. Cit

1 Pasal 21 ayat (1) UU UMKM

2 Pasal 21 ayat (2) UU UMKM

43 Pasal 21 ayat (3) UU UMKM

44 Pasal 21 ayat (4) UU UMKM
} 
bentuk kemudahan persyaratan perizinan, keringanan tarif sarana dan prasarana, dan bentuk insentif lainnya yang sesuai dengan ketentuan peraturan perundang-undangan kepada dunia usaha yang menyediakan pembiayaan bagi Usaha Mikro dan Kecil. ${ }^{45}$ Hal ini juga bermakna sebagai pemberian fasilitas yang ditujukan untuk memudahkan UMKM. Akan tetapi, perlu juga diingat bahwa ketentuan dalam norma-norma tersebut hanya menggunakan kata "dapat". Penggunaan kata "dapat" ini berarti tidak mewajibkan untuk dilaksanakan.

Adapun mengenai Pembiayaan dan Penjaminan Usaha Menengah diatur secara singkat dalam Pasal 24 UU UMKM. ${ }^{46}$ Pengaturan tersebut secara pokok menekankan pada peningkatan pembiayaan modal dan investasi melalui pasar modal, lembaga pembiayaan, lembaga penjamin kredit, dan lembaga penjamin ekspor. Penekanan dalam Pasal 24 ini menjadi ironis bagi UMKM orang-perorangan dalam menjalankan usahanya. Terlebih apabila berbicara pembiayaan melalui pasar modal, maka secara otomatis bentuk UMKM tersebut sudah harus berbentuk PT. Artinya, UU UMKM pun secara tidak langsung sudah menyadari bahwa masalah pembiayaan modal bagi UMKM dapat lebih maksimal apabila UMKM tersebut berbentuk PT.

Selain daripada itu, salah satu kebijakan Pemerintah dalam mendukung EoDB khususnya terkait kemudahan memulai usaha (Starting Business) dapat dilihat melalui perubahan ketentuan modal dasar untuk mendirikan PT. Dimana dalam Pasal 32 ayat (1) UUPT, diatur bahwa modal dasar Perseroan yang disetor paling sedikit berjumlah Rp 50.000.000,00 (lima puluh juta rupiah). Pemerintah kemudian menerbitkan Peraturan Pemerintah No. 7 Tahun 2016 tentang Perubahan Modal Dasar Perseroan Terbatas. ${ }^{47}$ Dengan diterbitkannya peraturan tersebut, maka modal minimum bagi UMKM untuk mendirikan PT ditentukan berdasarkan kesepakatan para pendiri saja. Dengan diterbitkannya peraturan tersebut, Pemerintah mendorong agar UMKM mau mendirikan usahanya dalam bentuk PT.

3) Rendahnya kualitas operasional organisasi. Meskipun secara statistik UMKM sudah mulai banyak muncul di tengah masyarakat, dalam prakteknya UMKM yang benar-benar beroperasi sesuai dengan kaidah hukum yang terkait masih sangat sedikit. Sebagai contoh, untuk jenis badan usaha berbentuk firma atau Commanditaire Venootschap (CV), para sekutu tidak melakukan hal yang sebagaimana mestinya. Selain itu, UMKM secara umum masih belum melakukan tata

Pasal 24 ayat (5) UU UMKM.

46 Pasal 24 UU UMKM berbunyi:

Pemerintah dan Pemerintah Daerah melakukan pemberdayaan Usaha Menengah dalam bidang pembiayaan dan penjaminan dengan:

a. memfasilitasi dan mendorong peningkatan pembiayaan modal kerja dan investasi melalui perluasan sumber dan pola pembiayaan, akses terhadap pasar modal, dan lembaga pembiayaan lainnya; dan

b. mengembangkan lembaga penjamin kredit, dan meningkatkan fungsi lembaga penjamin ekspor.

47 Selanjutnya peraturan tersebut dicabut dan diganti dengan Peraturan Pemerintah No. 29 Tahun 2016 tentang Perubahan Modal Dasar Perseroan Terbatas, yang pada intinya membuka peluang bagi seluruh jenis bidang usaha agar dapat mendirikan PT dengan modal yang disepakati para pihak. World Bank dalam survei EoDB-nya mencatat bahwa ketentuant tersebut memungkinkan bagi PT untuk dapat didirikan dengan modal Rp 0,- (nol rupiah). Meskipun secara teori, hal ini kurang tepat bagi bentuk usaha PT karena PT adalah persekutuan modal. 
kelola badan usaha dengan baik (Good Corporate Governance).

4) Rendahnya kualitas koperasi. Salah satu bentuk badan usaha yang seharusnya dapat dipercaya dalam berusaha adalah koperasi. Dalam menjalankan koperasi, banyak faktorfaktor yang harus diselenggarakan secara bersama-sama antara pendiri, pengurus, dan pekerja. Hal ini tidak dilaksanakan dengan benar karena pada dasarnya koperasi-koperasi di Indonesia tidak taat asas dengan aturan-aturan koperasi yang lebih terstruktur. Sehingga koperasi yang seharusnya dapat dijadikan badan usaha formal bagi UMKM, malah menjadi badan usaha yang tidak mematuhi peraturan yang berlaku. Di sisi lain, persyaratan untuk mendirikan koperasi yang harus didirikan sekurang-kurangnya oleh 20 (dua puluh) orang dalam Pasal 6 ayat (1) Undang-undang No. 25 Tahun 1992 Tentang Perkoperasian, semakin bertentangan dengan semangat usaha perorangan yang terdapat dalam UU UMKM. Maka dari itu, saat ini Pemerintah mendorong UMKM untuk segera memformalkan bentuk badan usahanya dalam bentuk PT.

5) Iklim usaha yang tidak kondusif. UMKM pada dasarnya berada dalam iklim usaha yang tidak kondusif di Indonesia. Bappenas menguraikan hal tersebut diakibatkan oleh ketidakpastian dan ambivalensi dalam prosedur perizinan untuk UMKM sehingga biaya usahanya menjadi tinggi (termasuk biaya illegal atau pungutan liar), iklim bisnis yang tidak sehat, dan lemahnya koordinasi antarlembaga untuk mendukung UMKM.

\section{d. Banyaknya UMKM yang tidak berbentuk usaha formal}

Sebagaimana telah dijelaskan diatas mengenai kendala-kendala bagi UMKM, maka setidaknya mengubah pola UMKM sebagai badan usaha informal menjadi formal adalah salah satu upaya untuk memberikan kepastian hukum bagi UMKM. Hal ini berkaca pada fakta bahwa jenis usaha besar yang memiliki produktivitas, laba, dan aset yang lebih baik ketimbang UMKM mayoritas telah berbentuk badan usaha formal.

Berdasarkan hasil studi yang dilakukan oleh World Bank, saat ini jenis UMKM berbadan usaha informal atau tanpa bentuk usaha yang jelas, jauh lebih banyak ketimbang UMKM berbadan usaha formal dalam bentuk PT, CV, Firma, dan sebagainya ${ }^{48}$ dengan rentang jumlah 70 juta s.d. 100 juta UMKM formal dan 285 juta s.d. 345 juta UMKM informal. ${ }^{49}$ Di sinilah World Bank pun menilai bahwa UMKM akan lebih stabil dalam menjalankan usahanya apabila sudah berbentuk formal, karena akan mendapatkan akses pendanaan yang lebih baik, profit yang lebih baik, dan berdampak pada meningkatnya pajak negara. ${ }^{50}$

Dengan demikian, dapat disimpulkan bahwa seyogyanya UMKM perlu didorong agar segera berdiri dalam bentuk badan usaha formal. Mengingat saat ini badan usaha di Indonesia yang mampu memberikan kepastian hukum terbaik adalah PT, maka UMKM juga perlu

\footnotetext{
48 The World Bank, "Small And Medium Enterprises (SMEs) Finance: Improving SMEs' Access to Finance and Finding Innovative Solutions to Unlock Sources of Capital.", Op.Cit.

49 Ibid.

50 Ibid.
} 
didorong dengan membentuk PT. Dorongan sebagaimana dimaksud tentu saja dengan memberikan berbagai fasilitas dan akses kemudahan bagi UMKM untuk mendirikan PT.

\section{Gagasan Usaha Mikro, Kecil, dan Menengah berbentuk Perseroan Terbatas}

Sebagaimana telah disinggung diatas, ketentuan bahwa UMKM dapat didirikan oleh "orang perorangan" dalam UU UMKM tentunya menjadi menarik apabila dikaitkan dengan UMKM yang ingin didirikan dalam bentuk PT. Pasalnya di Indonesia saat ini untuk mendirikan PT, hal pertama yang perlu dilakukan adalah mencari mitra yang memiliki tujuan sama untuk mendirikan PT tersebut. Hal ini dikarenakan PT di Indonesia hanya dapat didirikan oleh dua orang atau lebih sesuai dengan bunyi Pasal 1 Ayat (1) UUPT di mana PT adalah adalah badan hukum yang merupakan persekutuan modal, didirikan berdasarkan perjanjian, melakukan kegiatan usaha dengan modal dasar yang seluruhnya terbagi dalam saham dan memenuhi persyaratan lainnya sesuai peraturan perundang-undangan. Selanjutnya dalam Pasal 7 ayat (1) UUPT diatur bahwa PT didirikan oleh 2 (dua) orang atau lebih dengan akta notaris yang dibuat dalam bahasa Indonesia. Dengan kata lain, satu orang individu tidak dapat mendirikan PT seorang sendiri.

Secara historis, filosofi pendirian PT di Indonesia harus dilakukan oleh dua orang atau lebih berangkat dari ketentuan dalam Kitab Undang-Undang Hukum Perdata Indonesia atau Burgerlijk Wetboek (selanjutnya disebut BW). Pasal 1653 BW mengamanatkan bahwa PT merupakan perkumpulan orang-orang sebagai badan hukum. Selain itu, pembahasan mengenai PT dalam BW disinggung secara singkat dalam Buku Ketiga tentang Perikatan, Bab IX tentang Badan Hukum (Van Zedelijke Ligchamen). ${ }^{51}$ Di mana dalam bab sebelumnya yaitu Bab VIII, yang diatur adalah mengenai Persekutuan Perdata (Van Maatschap). Artinya, secara sistematika memang konsep yang dibangun oleh para legislator BW pada zaman dahulu memang badan hukum PT merupakan bagian dari Persekutuan Perdata. Akan tetapi, PT memiliki karakteristik yang berbeda dengan Persekutuan Perdata pada umumnya: mengakui tanggung jawab terbatas antara subyek hukum dengan badan usaha yang didirikan. Penggunaan frase "Para Persero" dalam Pasal 36 s.d. 56, Bagian 3 BW tentang Perseroan Terbatas, Kitab Undang-undang Hukum Dagang/Wetboek van Koophandel (WvK) juga menyiratkan makna bahwa, PT memang merupakan bentuk persekutuan perdata berbadan hukum.

Dengan adanya frase "didirikan berdasarkan perjanjian" dalam UUPT, maka untuk membentuk PT, langkah selanjutnya adalah membuat perjanjian pendirian PT antara para 
inisiator atau calon pemodal awal. ${ }^{52} \mathrm{Hal}$ ini semakin menegaskan perlunya dua orang atau lebih untuk mendirikan PT karena dalam sistem hukum Indonesia, perjanjian harus tunduk dengan ketentuan dalam syarat sah perjanjian khususnya Pasal 1320 BW. ${ }^{53}$

Perjanjian pendirian sebagaimana dimaksud harus dibuat dengan Akte Notaris. Artinya, perjanjian pendirian PT tersebut tidak dapat dibuat di bawah tangan, tetapi harus dibuat oleh Notaris yang ditunjuk untuk membuat akta pendirian tersebut. Maka dari itu, prinsip konsensual dalam hukum perjanjian tidak serta merta dapat diaplikasikan mengingat kewajiban perjanjian tersebut dituangkan dalam Akta Autentik. ${ }^{54}$ Lebih lanjut dalam Pasal 7 Ayat (4) UUPT juga ditentukan bahwa suatu PT baru memiliki status badan hukum pada tanggal diterbitkannya Keputusan Menteri Hukum dan Hak Asasi Manusia (Menkumham) mengenai pengesahan badan hukum PT yang bersangkutan. Ketentuan ini menegaskan bahwa perbuatan hukum PT sebagai badan hukum mulai berlaku sejak tanggal diterbitkan keputusan menteri mengenai pengesahan badan hukum PT. ${ }^{55}$ Maka dari itu, tindakan hukum sebelum pengesahan tersebut menjadi tanggung jawab setiap pendiri secara tanggung renteng. ${ }^{56}$

Dari sini dapat diketahui bahwa PT telah sah berdiri dan memiliki status badan hukum dengan adanya otorisasi dari Pemerintah. ${ }^{57}$ Hal ini tentunya berbeda dengan konsep Persekutuan Perdata murni yang diatur dalam Pasal 1624 BW, di mana Persekutuan Perdata mulai sah terbentuk setelah perjanjian pendiriannya disepakati para pihak tanpa suatu otorisasi Pemerintah. ${ }^{58}$

Atas pemikiran tersebut, Penulis mengasumsikan bahwa pada dasarnya hal utama untuk mendirikan suatu PT adalah lahirnya status badan hukum melalui pengesahan oleh Pemerintah. Tanpa pengesahan tersebut maka PT yang bersangkutan, meskipun dalam klausul perjanjian pendiriannya disebutkan bahwa bentuk usaha yang didirikan adalah PT, hanya akan berbentuk Persekutuan Perdata biasa.

52 Agus Sardjono, et al., Pengantar Hukum Dagang, (Jakarta: Raja Grafindo Persada, 2014), hlm. 4.

53 Pasal 1320 BW berbunyi: Supaya terjadi perjanjian yang sah, perlu dipenuhi empat syarat:

- $\quad$ kesepakatan mereka yang mengikatkan dirinya;

- $\quad$ kecakapan untuk membuat suatu perikatan;

- $\quad$ suatu pokok persoalan tertentu;

- $\quad$ suatu sebab yang tidak terlarang.

54 Yang dimaksud dengan Akta Autentik dalam UUPT dikenal dengan Akta Notaris. Hal ini terdapat dalam Pasal 7 ayat (1) UUPT yang berbunyi: Perseroan didirikan oleh 2 (dua) orang atau lebih dengan akta notaris yang dibuat dalam bahasa Indonesia.

55 Freddy Harris \& Teddy Anggoro, Hukum Perseroan Terbatas : Kewajiban Pemberitahuan oleh Direksi, (Bogor: Ghalia Indonesia, 2010), hlm. 21.

56 Ibid.

57 Hal ini juga dipertegas dengan tidak diakuinya tindakan hukum pendiri PT apabila PT tersebut belum mendapatkan pengesahan oleh Menkumham, kecuali tindakan hukum tersebut diakui sebagai tindakan PT dalam Rapat Umum Pemegang Saham (RUPS) sebagaimana diatur dalam Pasal 13 Ayat (1) UUPT: "Perbuatan hukum yang dilakukan calon pendiri untuk kepentingan Perseroan yang belum didirikan, mengikat Perseroan setelah Perseroan menjadi badan hukum apabila RUPS pertama Perseroan secara tegas menyatakan menerima atau mengambil alih semua hak dan kewajiban yang timbul dari perbuatan hukum yang dilakukan oleh calon pendiri atau kuasanya."

58 Pasal 1624 BW berbunyi: "Perseroan perdata mulai berjalan pada saat persetujuan diadakan, kecuali jika ditentukan waktu lain dalam persetujuan itu." 
Perspektif ini tentunya mengisyaratkan bahwa PT baru dapat disebut sebagai badan hukum apabila terdapat otorisasi Pemerintah. Dimana hal ini berarti Pemerintah berhak menentukan kriteria PT yang bahkan dapat berbeda konsep dengan Persekutuan Perdata murni. Sebagai badan hukum yang disahkan Pemerintah, tentunya Pemerintah juga memiliki hak untuk menentukan apa saja syarat-syarat suatu PT dapat disahkan atas pertimbangan sendiri.

\section{Perseroan Terbatas Persekutuan Modal}

Merujuk ke Pasal 1 Ayat (1) UUPT, PT di Indonesia dapat diklasifikasikan memiliki 4 (empat) unsur utama yaitu: berbentuk badan hukum; merupakan persekutuan modal, didirikan berdasarkan perjanjian; dan melakukan kegiatan dengan modal dasar yang terbagi dalam saham. PT sebagai persekutuan modal maksudnya adalah PT menghimpun atau mengumpulkan modal sebesar-sebesarnya dengan tujuan mendapatkan keuntungan yang juga sebesar-besarnya.

Sebagai badan usaha yang didirikan dengan maksud mencapai keuntungan sebesarbesarnya, maka PT juga membutuhkan modal yang mampu menggerakkan roda organisasi PT secara maksimal. Maka dari itulah, PT dikenal sebagai perkumpulan modal karena pada dasarnya PT memang dibentuk untuk menghimpun modal sebesar-besarnya demi mencapai keuntungan yang maksimal. Paham ini juga merupakan pandangan global mengenai konsep PT di seluruh dunia.

Penegasan PT sebagai persekutuan modal memiliki makna bahwa PT tidak mementingkan sifat kepribadian para pemegang saham yang ada di dalamnya. ${ }^{59}$ Sebagai persekutuan modal, PT lebih berpotensi untuk menghimpun modal sebesar-besarnya dibandingkan dengan Firma atau $\mathrm{CV}^{60}$ Salah satu alasan utama mengapa PT lebih mudah dalam menghimpun dana adalah kepemilikan PT yang berbentuk saham. Untuk mendapatkan tambahan modal, pihak PT cukup menjual saham baru, dimana saham tersebut dapat dijual kepada pihak investor untuk meningkatkan modal usaha. Selain daripada itu, pengalihan hak atas saham atau pemindahtanganan kepemilikan dalam PT cukup mudah. Caranya cukup dengan melakukan jual beli saham antara pemegang saham lama dengan calon pemegang saham baru. Hal inilah yang menjadi alasan mengapa PT lebih mudah menghimpun dana dibandingkan dengan Firma atau CV.

Selain daripada hal tersebut di atas, dalam mekanisme jual beli saham dikenal istilah pasar modal. Pasar modal adalah salah satu sarana bagi PT yang ingin menghimpun dana publik untuk digunakan sebagai modal PT. ${ }^{61}$ Selain itu, pasar modal terdapat di berbagai kota-kota besar di seluruh dunia. Sehingga proses transaksi saham di pasar modal relatif lebih luas dan tidak mengenal batasan jarak dalam mempertemukan pembeli dan penjual saham. Namun perlu diingat bahwa modal yang dimaksud disini adalah modal saham, dan 
bukan modal kerja yang biasanya diperoleh atau bersumber dari pinjaman bank. ${ }^{62}$

Jika kita melihat pengaturan PT di beberapa negara maju, konsep PT sebagai badan hukum di Amerika juga dikenal dalam bentuk Limited Liability Company (LLC). Menurut Bainbridge, salah satu ciri utama LLC adalah pendiriannya didasarkan pada adanya perkumpulan modal untuk mendirikan LLC (Association of Capital). ${ }^{63}$ Bainbridge lebih lanjut menyatakan bahwa di Amerika Serikat, PT dapat didirikan cukup oleh 1 (satu) orang saja. ${ }^{64}$ Sedangkan di Inggris Raya, pendirian PT juga dimungkinkan dilakukan oleh 1 (satu) orang pendiri saja. Hal ini terlihat dalam Pasal 7 ayat (1) Companies Act 2006 yang berbunyi: "A company is formed under this Act by one or more persons".

Sebagai negara yang mengadopsi sistem hukum Belanda, Belanda sendiri sejak tahun 1992 melalui Nieuw Burgerlijk Wetboek (Kitab Undang-undang Hukum Perdata Belanda) telah membuka peluang bahwa PT dapat didirikan oleh 1 (satu) orang saja. Hal ini dapat dilihat dalam terjemahannya pada Buku 2 mengenai Legal Persons, Title 4 mengenai Companies Limited By Shares, Bagian 1 Pasal 64 ayat 2: "A company shall be incorporated by one or more persons by notarial deed". Ironis ketika Indonesia menerbitkan UU PT pada tahun 2007 masih mengadopsi sistem hukum lama Belanda. Dimana pada tahun 1992 Belanda sudah membuka pintu bagi PT untuk didirikan oleh perorangan.
Fakta tersebut diperkuat oleh pernyataan Agus Sardjono. Beliau mengatakan bahwa memang pada dasarnya, PT adalah persekutuan modal (Association of Capital). ${ }^{65} \mathrm{Hal}$ ini berbeda dengan bentuk usaha persekutuan, baik Firma maupun CV yang merupakan perkumpulan orang-orang (Association of Persons). ${ }^{66}$ Kewajiban PT harus didirikan melalui perjanjian antara dua orang atau lebih merupakan konsep yang ditetapkan oleh legislator Indonesia dengan mengadopsi aspek historis ketentuan yang terdapat dalam BW. Dimana PT merupakan perhimpunan orang-orang. Dari uraian singkat ini dapat dipastikan bahwa PT seyogyanya dapat didirikan oleh orang-perorangan karena PT merupakan kumpulan modal, bukan kumpulan orang. Sehingga tidak perlu lagi adanya kewajiban didirikan oleh minimum 2 (dua) orang atau lebih.

\section{Kepemilikan Saham Tunggal (Single Shareholder) dalam Perseroan Terbatas di Indonesia}

Secara tegas UUPT mensyaratkan minimum terdapat 2 (dua) pendiri untuk mendirikan PT sebagaimana telah dibahas sebelumnya. Namun dalam prakteknya di Indonesia, terdapat celah regulasi yang memang memungkinkan untuk suatu PT sahamnya dikuasai oleh 1 (satu) pendiri dan pemegang saham secara terbatas (Single Shareholder). Yakni PT milik negara atau Badan Usaha Milik Negara (selanjutnya disebut BUMN), dan PT dalam keadaan pemegang sahamnya menjadi kurang dari 2 (dua) orang.

\footnotetext{
Ibid.

63 Stephen M. Bainbridge, Limited Liability Companies: A Primer on Value Creation through Choice of Form, Coporation and Economics, (Los Angeles: Foundation Press, 2001), hlm. 3.

64 Freddy Harris, Op. Cit., hlm. 18.

65 Agus Sardjono, Op. Cit., hlm. 73.
}

66 Ibid. 
Meskipun UUPT mensyaratkan minimum terdapat 2 (dua) pendiri untuk mendirikan PT, terdapat ketentuan Lex Specialis dalam Pasal 1 Angka 2 Undang-undang No. 19 Tahun 2003 Tentang Badan Usaha Milik Negara yang mengatur bahwa BUMN dapat dimiliki Pemerintah secara tunggal. ${ }^{67}$ Ketentuan ini menegaskan bahwa di Indonesia dimungkinkan suatu PT BUMN didirikan oleh satu pendiri, dalam hal ini Pemerintah Indonesia. Secara historis, Undang-undang ini disahkan lebih dulu daripada UUPT. Artinya, memang pada saat penyusunan UUPT tahun 2007 sudah ada suatu keadaan hukum dimana dimungkinkan suatu PT didirikan dan dimiliki sahamnya oleh 1 (satu) pendiri saja. Meskipun PT yang dimaksud adalah PT BUMN yang memang diperbolehkan untuk mendapatkan keistimewaan tertentu (privilege) dari Pemerintah.

Dengan didirikan oleh 2 (dua) orang atau lebih, tentunya terdapat kemungkinan salah satu pemegang saham suatu PT melepas sahamnya ke pemegang saham yang satunya. Hal ini sudah diperhitungkan oleh para legislator UUPT. Dalam UUPT hal ini diantisipasi dengan dimungkinkannya suatu PT dimiliki oleh 1 (satu) orang pemegang saham saja secara limitatif. ${ }^{68}$ Limitasinya yaitu dalam jangka waktu paling lama 6 (enam) bulan terhitung sejak keadaan tersebut, pemegang saham yang bersangkutan wajib mengalihkan sebagian sahamnya kepada orang lain atau PT mengeluarkan saham baru kepada orang lain. Ketentuan ini menegaskan bahwa kepemilikan atas saham suatu PT tidak boleh dimonopoli oleh 1 (satu) orang. Maka dari itu, dalam hal suatu PT yang hanya memiliki 1 (satu) pemegang saham saja dalam waktu 6 (enam) bulan setelah mendapatkan pengesahan badan hukum, pemegang saham tunggal tersebut harus menjual sahamnya kepada orang lain atau menerbitkan saham baru untuk dijual kepada orang lain sehingga saham PT tersebut tidak hanya dimiliki oleh 1 (satu) orang pemegang saham saja. ${ }^{69}$

Konsekuensi dalam hal jangka waktu 6 (enam) bulan tersebut telah dilampaui namun pemilik sahamnya tetap tunggal, maka pemilik saham yang bersangkutan bertanggung jawab secara pribadi atas segala perikatan dan kerugian PT. ${ }^{70}$ Selain itu, atas permohonan pihak yang berkepentingan, pengadilan negeri dapat membubarkan PT tersebut. Pihak berkepentingan dalam hal ini adalah kejaksaan untuk kepentingan umum, pemegang saham, Direksi, Dewan Komisaris, karyawan Perseroan, kreditor, dan/atau stakeholders lainnya. ${ }^{71}$

67 Pasal 1 Angka 2 Undang-undang No. 19 Tahun 2003 Tentang Badan Usaha Milik Negara berbunyi: "Perusahaan Perseroan, yang selanjutnya disebut Persero, adalah BUMN yang berbentuk perseroan terbatas yang modalnya terbagi dalam saham yang seluruh atau paling sedikit $51 \%$ (lima puluh satu persen) sahamnya dimiliki oleh Negara Republik Indonesia yang tujuan utamanya mengejar keuntungan.

68 Pasal 7 ayat (5) UUPT berbunyi: Setelah Perseroan memperoleh status badan hukum dan pemegang saham menjadi kurang dari 2 (dua) orang, dalam jangka waktu paling lama 6 (enam) bulan terhitung sejak keadaan tersebut pemegang saham yang bersangkutan wajib mengalihkan sebagian sahamnya kepada orang lain atau Perseroan mengeluarkan saham baru kepada orang lain.

69 Ibid.

70 Pasal 7 Ayat 6 UUPT berbunyi: Dalam hal jangka waktu sebagaimana dimaksud pada ayat (5) telah dilampaui, pemegang saham tetap kurang dari 2 (dua) orang, pemegang saham bertanggung jawab secara pribadi atas segala perikatan dan kerugian Perseroan, dan atas permohonan pihak yang berkepentingan, pengadilan negeri dapat membubarkan Perseroan tersebut.

71 Ibid. 
Meskipun ada pembatasan jangka waktu kepemilikan saham tunggal, faktanya legislator UUPT sudah memprediksikan kemungkinan keadaan suatu PT setelah disahkan dimiliki oleh 1 (satu) pemegang saham saja. Namun demikian, legislator menghiraukan keadaan ini dan tetap menekankan bahwa PT harus tetap didirikan oleh 2 (dua) orang atau lebih.

Selain daripada itu, tidak diatur pula apabila pemegang saham tunggal yang beritikad baik, gagal menjual sahamnya kepada pihak lain. Akan sangat ironis apabila kegagalan penjualan tersebut yang diluar kehendak pemegang saham tunggal, mengakibatkan perbuatan hukum PT yang bersangkutan menjadi tanggung jawab pribadi pemegang saham. Hal ini tentu berseberangan dengan konsepsi pemisahan tanggung jawab dalam badan hukum itu sendiri.

Kedua penjelasan diatas menunjukkan bahwa terdapat situasi-situasi tertentu dimana dimungkinkan suatu PT dapat didirikan sendiri, dan dapat pula dimiliki oleh satu pemegang saham saja. Dalam konteks pemegang saham berkurang menjadi pemegang saham tunggal, tentunya keadaan ini bukanlah keadaan yang diharapkan terjadi oleh legislator, namun legislator menyadari bahwa hal ini adalah suatu keadaan yang mungkin terjadi di masa yang akan datang. Sayangnya, hal tersebut tidak diatur lebih komprehensif dan legislator lebih berpegang pada konsepsi bahwa PT harus didirikan oleh 2 (dua) orang atau lebih.

\section{Penutup}

UMKM memang dapat menjadi solusi jangka pendek maupun jangka panjang perekonomian nasional. Dalam pembahasan diatas secara jelas diketahui bahwa UMKM berbentuk informal akan mengalami kesulitan pembiayaan. Terlebih lagi, UU UMKM sendiri mengklasifikasikan pasar modal sebagai solusi pendanaan bagi UMKM. Hal ini secara jelas memang mensyaratkan bahwa UMKM akan dapat menjalankan bisnisnya dengan lebih baik apabila berbentuk PT. Selain itu, dengan berbentuk informal, banyak pengusaha UMKM yang pada akhirnya gagal dalam menjalankan bisnisnya. Keadaan tersebut diperparah dengan adanya utang dan kerugian lainnya yang berimbas pada harta pribadi. Dengan demikian, upaya Pemerintah untuk meningkatkan kesejahteraan masyarakat justru dapat berimbas pada meningkatnya angka kemiskinan akibat bankrut.

Memang dengan mengubah bentuk bisnis informal menjadi berbentuk PT, tidak secara otomatis akan meningkatkan jumlah UMKM di Indonesia. Namun setidaknya, dengan berbentuk PT mencerminkan pengelolaan UMKM yang lebih profesional, dan berpotensi menarik minat investor untuk memberikan bantuan atau pinjaman. Selain daripada itu, PT sebagai badan hukum yang mengenal pemisahan harta pribadi dengan harta perusahaan dapat memberikan perlindungan dalam hal perusahaan terjadi pailit. Disini Pemerintah sebagai regulator juga memberikan suatu perlindungan bagi masyarakat agar tidak jatuh miskin akibat utang. Hal ini akan dapat terwujud apabila orang perorangan dapat memulai UMKM dalam bentuk PT (Single Shareholder) tanpa harus mencari mitra terlebih dahulu.

Atas dasar pemikiran tersebut, sudah sewajarnya PT dapat didirikan secara tunggal tanpa harus dipersyaratkan 2 (dua) orang minimum. Permasalahan ini harus menjadi salah satu fokus dalam revisi peraturan mengenai PT nantinya. Baik itu dalam revisi UUPT maupun dalam penyusunan RUU Badan Usaha. Apabila hal ini dapat diterapkan, maka Pemerintah tidak hanya mendorong kemudahan berusaha bagi 
UMKM di Indonesia, tetapi juga memperbaiki disharmoni yang ada antara UUPT dan UU UMKM terkait memulai UMKM.

\section{Daftar Pustaka}

\section{Buku}

Ali, Zainuddin, Metode Penelitian Hukum, (Jakarta: Sinar Grafika,2010)

Bainbridge, Stephen M. Limited Liability Companies: A Primer on Value Creation through Choice of Form, Coporation and Economics, (Los Angeles: Foundation Press, 2001)

Harris, Freddy \& Teddy Anggoro, Hukum Perseroan Terbatas: Kewajiban Pemberitahuan oleh Direksi, (Bogor: Ghalia Indonesia, 2010).

Mamudji, Sri, Et. Al., Metode Penelitian dan Penulisan Hukum, (Jakarta: Badan Penerbit Fakultas Hukum Universitas Indonesia, 2005).

Radjagukguk, Erman. Hukum Investasi dan Pasar Modal, (Jakarta: Badan Penerbit Fakultas Hukum Universitas Indonesia, 2013).

Ridho, Ali. Badan Hukum dan Kedudukan Badan Hukum Perseroan, Perkumpulan, Koperasi, Yayasan, dan Wakaf, (Bandung: Alumni, 1999).

Sardjono, Agus, et al., Pengantar Hukum Dagang, (Jakarta: Raja Grafindo Persada, 2014).

\section{Makalah/Artikel/Prosiding/Hasil Penelitian}

Taufik, Ade Irawan, "Evaluasi Regulasi dalam Menciptakan Kemudahan Berusaha bagi UMKM", Jurnal Rechtsvinding, Volume 6 Nomor 3 (2017), https://rechtsvinding.bphn. go.id/jurnal/680030JURNAL\%20VOLUME\%20 6\%20NO\%203_rev\%202.pdf (diakses pada 16 September 2018).

\section{Internet}

Bank Indonesia, "Kajian Inkubator Bisnis dalam rangka Pengembangan UMKM" , Kajian dan Publikasi Sektor Riil Bank Indonesia, http://www. bi.go.id/id/umkm/penelitian/nasional/kajian/ Pages/riil6.aspx. (diakses pada 11 September 2018).

Esuh Ossai-Igwe Lucky, "Is Small and Medium (SMEs) an Enterpreneurship?" Human Resource Management Academic Research http:// www.hrmars.com/admin/pics/545.pdf Society (diakses pada 12 September 2018).

European Union, "Think Small First" - A "Small Business Act", European", EUR-Lex, http:// eur-lex.europa.eu/legal-content/EN/ TXT/?uri=CELEX:52008DC0394 (diakses pada 14 September 2018).

Growth: Internal Market, Industry, Entrepreneurship and SMEs, "Entrepreneurship and Small and medium-sized enterprises", European Union https://ec.europa.eu/growth/smes_en (diakses pada 12 September 2018).

Growth: Internal Market, Industry, Entrepreneurship and SMEs, "Promoting entrepreneurship" European Union, https://ec.europa.eu/growth/ smes/promoting-entrepreneurship_en (diakses pada 12 September 2018).

Kantor Menteri Negara Perencanaan Pembangunan Nasional (BAPPENAS), "Empowerment of Cooperatives and Micro, Small, and Medium Enterprise", https://www.bappenas. go.id/files/8913/4986/4554/chapter-20empowerment-of-cooperatives-and-microsmall-and-medium-enterprise.pdf (diakses pada 23 September 2018).

OECD, "OECD Studies on SMEs and Entrepreneurship", OECD iLibrary, https:// www.oecd-ilibrary.org/industry-and-services/ sme-and-entrepreneurship-policy-in-israel2016_9789264262324-en

Ridwan Khairandi, "Badan Usaha Milik Negara" Fakultas Hukum Universitas Islam Indonesia, http://law.uii.ac.id/images/stories/KaryaIImiah-Dosen/Buku-Prof-Ridwan-Khairandy/ Bab7/ISI\%20KOmplet-2_hal\%20\%20167.pdf. (diakses pada 25 September 2018).

The World Bank Group, "Doing Business 2018: Reforming Business to Create Jobs", The World Bank Group Flagship Report, http:// www.doingbusiness.org/content/dam/ doingBusiness/country/i/indonesia/IDN.pdf (diakses pada 14 September 2018).

The World Bank, "About Doing Business" http:// www.doingbusiness.org/content/dam/ doingBusiness/media/Annual-Reports/English/ DB18-Chapters/DB18-About-Doing-Business. pdf (diakses pada 13 September 2018).

The World Bank, "Small And Medium Enterprises (Smes) Finance: Improving SMEs' access to finance and finding innovative solutions to unlock sources of capital." https://www. 
worldbank.org/en/topic/smefinance (diakses pada 13 September 2018).

\section{Peraturan Perundang-Undangan}

Indonesia, Undang-undang Badan Usaha Milik Negara, UU No. 19 Tahun 2003, LN No. 70 Tahun 2003, TLN No. 4362

, Undang-undang Perseroan Terbatas, UU No. 40 Tahun 2007, LN No. 106 Tahun 2007, TLN No. 4756.
Undang-undang Usaha Mikro, Kecil, dan Menengah, UU No. 20 Tahun 2008, LN No. 93 Tahun 2008, TLN No. 4866.

, Peraturan Pemerintah Perubahan Modal

Dasar Perseroan Terbatas, PP No. 7 Tahun 2016, LN No. 54 Tahun 2016, TLN No. 5862.

Belanda, Nieuw Burgerlijk Wetboek 1992.

Inggris Raya, Companies Act 2006. 
"Halaman ini dikosongkan" 